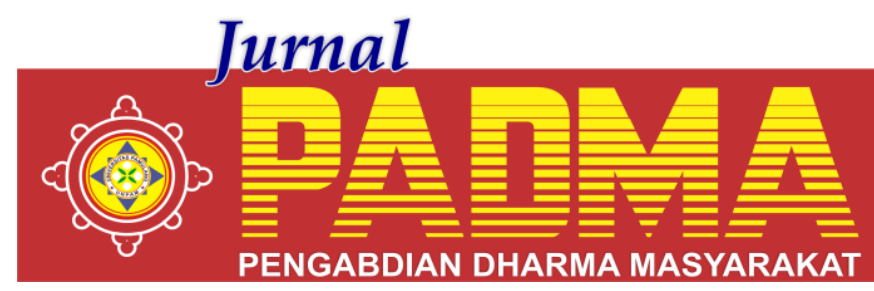

VOLUME 1, NOMOR 3, JULI 2021

\title{
STRATEGI PEMBERDAYAAN IBU RUMAH TANGGA UNTUK BERWIRAUSAHA GUNA MENINGKATKAN PENDAPATAN EKONOMI KELUARGA
}

\author{
${ }^{1}$ Agil Caturiyan, ${ }^{2}$ Farhda Amelia Yusriani, ${ }^{3}$ Aprilia Cindy Clarista, ${ }^{4}$ Novita Ismianti, \\ $5^{*}$ Githa Enjelika \\ Universitas Pamulang, Tangerang Selatan, Banten, Indonesia \\ *githaenjelika07@gmail.com
}

\begin{abstract}
Abstrak
Strategi Pemberdayaan Ibu Rumah Tangga Untuk Berwirausaha Guna Meningkatkan Pendapatan Ekonomi Keluarga, hadir untuk memberikan memotivasi, dan membangkitkan kesadaran akan potensi yang dimilikinya serta berupaya untuk mengembangkan pengetahuan, wawasan, serta ide-ide dalam melakukan wirausaha. Tujuan dari penyuluhan Strategi Pemberdayaan Ibu Rumah Tangga ini untuk meningkatkan pendapatan ekonomi keluarga yang dimana khususnya ibu-ibu bisa timbul keinginan untuk berwirausaha dalam bidang olahan pangan dan mampu mendirikan UMKM.
\end{abstract}

Kata Kunci: Wirausaha, Pemberdayaan

\section{Abstract}

Strategies for Empowering Housewives for Entrepreneurship to Increase Family Economic Income, are here to motivate and raise awareness of their potential and strive to develop knowledge, insights, and ideas in doing entrepreneurship. The aim of the counseling for the Housewife Empowerment Strategy is to increase the economic income of the family, which in particular for mothers can arise a desire to become entrepreneurs in the field of food processing and be able to establish UMKM.

Keywords: Entrepreneurship, Empowerment

\section{PENDAHULUAN}

Pengabdian masyarakat adalah suatu kegiatan yang bertujuan membantu masyarakat tertentu dalam beberapa aktivitas tanpa mengharapkan imbalan dalam bentuk apapun. Secara umum program ini dirancang oleh berbagai universitas atau institut yang ada di Indonesia begitu pula di Universitas Pamulang (UNPAM) untuk memberikan kontribusi nyata bagi bangsa Indonesia.

Keberadaan ibu rumah tangga beserta hak dan kewajibannya dianggap sebagai suatu hukum alam yang secara alamiah memang harus dikerjakan oleh ibu rumah tangga. Tugas ibu rumah tangga adalah mengurus keluarga seperti memasak, membersikan rumah, merawat dan mendidik anak-anak. Ibu rumah tangga sebuah profesi yang seringkali diabaikan karena dianggap tidak memberikan kontribusi ekonomi didalam sebuah keluarga. Padahal tantangan ekonomi keluarga lebih banyak dirasakan oleh kaum ibu karena kegiatan mereka secara langsung dihadapkan pada barangbarang komsumsi kelurga setiap hari.

Lemahnya ekonomi keluarga membuat keterlibatan ibu rumah tangga dalam meningkatkan pendapatan keluarga dengan cara mencari pendapatan tambahan dengan bekerja seperti berdagang atau bekerja pada orang lain untuk mendapatkan upah. Terkait dengan usaha meningkatnya ekonomi keluarga, ibu rumah tangga perlu ditingkatkan kemampuan agar mampu membantu perekonomian keluarga. Upaya peningkatan tersebut dapat dilakukan melalui upaya pemberdayaan. Memberikan motivasi, pengetahuan mengenai pola pendampingan usaha, pelatihan keterampilan dan penyuluhan kewirausahaan merupakan beberapa cara pemberdayaan untuk membekali para perempuan agar bisa bekerja dan memiliki penghasilan dengan usahanya dirinya berdaya.

Hasil pengabdian masyarakat ini diharapkan dapat membentuk karakter masyarakat yang akan memotivasi terutama 
para ibu rumah tangga untuk berwirsusaha guna meningkatkan perekonomian keluarga.

Strategi merupakan alat untuk mencapai tujuan. Dalam perkembangannya, konsep mengenai strategi terus berkembang hal ini dapat ditunjukkan dengan adanya perbedaan konsep mengenai strategi selama beberapa tahun terakhir. Menurut (AB, Susanto, 2014:193-194) konsep strategi, disimpulkan bahwa strategi adalah suatu kesatun rencana yang menyeluruh, komprehensif, dan terpadu yang diarahkan untuk mencapai tujuan perusahaan.

Strategi itu sendiri memiliki kaitan yang erat dengan konsep perencanaan dan pengampilan keputusan, sehingga strategi berkembang menjadi manajemen strtegi. Strategi pembangunan yang bertumpuh pada pemihakan dan pemberdayaan dipahami sebagai suatu proses transformasi dalam hubungan social, ekonomi, budaya dan politik masyarakat. Perubahan structural yang diharapkan adalah proses yang berlangsung secara alamiah, yaitu yang menghasilkan harus menikmati. Begitu pula sebaliknya, yang menikmati haruslah yang menghasilkan.

Maka dari itu ada beberapa strategi menurut Laure (1982), yang dapat diterapkan dalam pemberdayaan ibu rumah tangga:

1. Strategi Redukatif

Strategi ini digunakan apabila diketahui adanya hambtan-hmbatan social budaya dalam upaya menerima suatu inovasi, terutama berkaitan dengan kelemahan pengetahuan atau pendidikan dan keterampilan dalam memamfaatkan suatu inovasi.

2. Strategi Persuasif

Strategi ini merupakan upaya melakukan perubahan masyarakat dengan cara membujuk masyarakat tersebut untuk melakukan perubahan (Nanang Martono.2011:258-259).

Sehingga dapat disimpulkan bahwa strategi adalah cara yang digunakan dalam menyelesaikan sesuatu dalam segala hal untuk mencapai tujuan yang diinginkan.

\section{METODE}

Metode yang digunakan dalam Pengabdian Kepada Masyarakat (PKM) ini yaitu metode berkomunikasi langsung kepada masyarakat dengan menerapkan protokol kesehatan. Setelah itu membahas apa saja yang menjadi kendala dalam melakukan usaha bagi Ibu-ibu yang yang belum memiliki usaha dalam masa pandemic ini dan memberikan Solusi yang dapat di terapkan yaitu Bisnis Kuliner dengan Memulai Bisnis Kue di Rumah.

Karena masa Pandemic saat ini bertepatan dengan masuknya bulan Ramadhan dan bisnis dadakan yang tepat berjualan kue di rumah. Bisnis yang satu ini pasti banyak dicari saat bulan Ramadhan, khususnya ketika mendekati Hari Raya Idul Fitri. Banyak dari masyarakat Indonesia yang merayakan Hari Raya dengan menyuguhkan kue kering sebagai camilan. Jadi untuk Ibu Rumah Tangga yang hobi membuat kue, bisnis ini akan menjadi ide yang tepat.

Memiliki kemampuan mengolah barang-barang menjadi sebuah kerajinan tangan menjadi pelung besar untuk dijadikan usaha bisnis. Kerajinan tangan yang banyak mendapat permintaan dari pasar bisa berupa souvenir wisuda, penghantar seserahan pernikahan, bahkan hingga pembuatan hampers untuk parsel dihari-hari special.

\section{HASIL DAN PEMBAHASAN}

Hasil dari kegiatan penyuluhan yang sudah kami lakukan yaitu Proses peningkatan kesejahteraan masyarakat dapat berbagai pendekatan, salah satunya adalah pemberdayaan masyarakat. Oleh karena itu, Pemberdayaan perempuan menjadi strategi penting dalam meningkatkan peran perempuan dalam meningkatkan potensi diri agar lebih mampu mandiri dan berkarya yang nantinya akan berstatus sebagai ibu rumah tangga guna. Karena perempuan merupakan sumber daya manusia yang sangat berharga sehingga posisinya di ikut sertakan dalam pembangunan. 03 RW.03 Pamulang Barat ini.

\section{PENUTUP}

Berdasarkan hasil kegiatan penyuluhan yang telah dilakukan mengen strategi pemberdayaan kaum perempua khusunya Ibu Rumah Tangga untuk berwirausaha guna meningkatkan 
pendapatan ekonomi keluarga dapat diambil beberapa kesimpulan, sebagai berikut :

1. Proses peningkatan kesejahteraan masyarakat dapat berbagai pendekatan, salah satunya adalah pemberdayaan masyarakat. Oleh karena itu, Pemberdayaan perempuan menjadi strategi penting dalam meningkatkan peran perempuan dalam meningkatkan potensi diri agar lebih mampu mandiri dan berkarya yang nantinya akan berstatus sebagai ibu rumah tangga guna. Hal ini didasarkan pada satu pemikiran mengenai perlunya kemandirian bagi kaum perempuan. Karena perempuan merupakan sumber daya manusia yang sangat berharga sehingga posisinya di ikut sertakan dalam pembangunan. Alasan itulah yang melatar-belakangi dilakukannya kegiatan penyuluhan yang bertujuan untuk memotivasi dan menggali potensi para ibu rumah tangga di Jl. Waru 2 RT. 03 RW. 03 Pamulang Barat ini. Melalui penyuluhan ini didapatkan bahwa keterlibatan pihak wargar menjadi elemen yang tak terbantahkan untuk mencapai hasil yang diharapkan sehingga nantinya po-tensi ibu rumah tangga yang sudah tergali tersebut bisa bersinergi dengan program masyarakat.

2. Sebagai ibu rumah tangga, istri harus mempunyai kreativitas dalam mengelola ekonomi keluarga. Keikutsertaan ibu rumah tangga dalam mencari nafkah untuk keluarga dapat membantu menunjang perekonomian dalam keluarga. Dari pemberdayaan perempuan untuk berwirausaha dapat diperoleh menambah penghasilan keluarga yang digunakan untuk memenuhi kebutuhankebutuhan keluarga sehari-hari, membiayai sekolah anak, merenovasi rumah, dan kebutuhan-kebutuhan lainnya.

3. Faktor yang mempengaruhi ibu rumah tangga bekerja dalam meningkatkan perekonomian keluarga ada beberapa faktor yang menjadi alasan ibu rumah tangga bekerja, (1) Dorongan untuk mencukupi kebutuhan ekonomi rumah tangga, (2) Ingin meringankan beban suami, (3) Lapangan pekerjaan yang tersedia, dan (4) Ingin menambah penghasilan sendiri.

4. Hambatan yang dihadapi Ibu rumah tangga di Jl. Waru 2 RT.03 RW.03 Pamulang Barat dalam meningkatkan pendapatan ekonomi keluarga dibagi menjadi dua, yaitu: faktor internal dan faktor eksternal. Faktor internal kurangnya motivasi dan potensi pada diri sendiria. Sedangkan faktor eksternal, kurangnya partisipsi kaum ibu rumah tangga dalam pelatihan pemberdayaan perempuan yang berhubungan dengan produktifitas wirausaha karena kesibukan dalam mengurus keluarga dan kurang tersedianya program-program dalam pemberdayaan perempuan.

\section{DAFTAR PUSTAKA}

Gunartin, G., et al (2020). The Role Analysis of Waste Bank in Improving the Community's Creative Economy (Study at Ketumbar Pamulang Waste Bank). Budapest International Research and Critics Institute (BIRCI-Journal): Humanities and Social Sciences, 3(4), 3262-3269.

Haque, M. G., Munawaroh, M., \& Sunarsi, D. (2020). Analysis of SMEs Culinary Marketing Strategy During Covid 19 Pancemic: A Study at "Sate Bebek Cilegon" Resto in Cilegon, Banten. International Journal of Education, Information Technology, and Others, $3(2), 447-451$.

Nurjaya, N., et al (2021). Pengaruh Etos Kerja Dan Disiplin Kerja Terhadap Kinerja Pegawai Pada Dinas Kehutanan Dan Perkebunan Kota Bogor. JENIUS (Jurnal Ilmiah Manajemen Sumber Daya Manusia), 4(2), 172-184.

Sunarsi, D., et al (2021). The Influence of Motivation and Work Discipline on Employee Performance at the Yogyakarta Tourism Service. Prosiding ICoGEMT, $\quad 1(1), \quad$ 1-7. 